Ankara Üniversitesi Eğitim Bilimleri Fakültesi

Özel Eğitim Dergisi

2014, 15(2) 81-93

\title{
Zihin Kuramı ve Dil Arasındaki İlişki: Bir Derleme
}

\author{
Bahar Keçeli Kaysılı * \\ Ankara Üniversitesi
}

Öz

Diğerlerinin duygularını, düşüncelerini ve isteklerini anlama yani zihin kuramı başarılı bir iletişim için gereklidir. Bu derleme çalışmasında normal gelişen çocuklarda zihin kuramı ve dil ilişkisi ele alınmıştır. Zihin kuramı kazanımını açıklayan teorilerden biri sözdizimi ve zihinsel durum ifade eden eylemlerin, yanlış inancın temsiline olanak să̆ladığını belirterek bu ilişkiyi incelemektedir. Bu varsayım dil ile zihin kuramı arasındaki ilişkinin doğasını tanımladığ iletişim ve dil gelişimlerini desteklemede, ögretmenlere yol göstereceği düşünülmektedir.

Anahtar Sözcükler: Zihin Kuramı, yanlış inanç, dil, anlam bilgisi, sözdizimi.

\begin{abstract}
Understanding of others' feelings, thoughts and wishes or a 'theory of mind' is essential for competent communication. This study described how language and theory of mind development are related in typically developing children. One of the hypothesis that explains the acquisition of theory of mind, proposed that syntax and mental states verbs provides children to understand representational thoughts like false belief. Because this hypothesis aimed to identify more specifically the nature of this role it is thought to be important. This review of selected literature will help teachers enhance children's communication and language development.
\end{abstract}

Keywords: Theory of mind, false belief, language, semantic, syntaxy

\footnotetext{
*Öğr. Gör. Dr., Ankara Üniversitesi, Eğitim Bilimleri Fakültesi, Özel Eğitim Bölümü, E-posta: bkaysili@ankara.edu.tr
} 
Yıllar boyunca farklı teorik açıklamalar zihin kuramını açıklamaya çalışmıştır. Kişinin kendisinin ve diğerlerinin zihinsel durumlarına atıfta bulunarak, "zihin kuramı" terimini ilk olarak alanyazına Premach ve Woodruff (1978) sunmuşlardır. Zihin kuramı terimi ile inanç, istek, niyet, hayal, duygu gibi zihinsel durumlardan çıkarsama yaparak eylemde bulunmak kastedilmektedir. Bu "çıkarsamalar sistemi” kuram olarak adlandırılmaktadır çünkü bu zihinsel durumlar doğrudan gözlenememekte ve bu sistem özellikle bir başkasının davranışlarıyla ilgili olarak tahminde bulunmayı içermektedir. Zihin kuramını açıklamaya çalışan teorik açıklamalar, zihin kuramında özellikle dört yaşlarında meydana gelen değişimlere odaklanmışlardır. Çocuklardört yaşlarında, karşıdaki kişinin zihinsel durumunu doğru okuyabilmekte ve yanlış inancı anlamaya doğru bir aşama kaydetmektedirler. Bu yaşlarda çocuklar karşıdaki kişinin düşüncesini göz önünde bulundurarak eylemlerini tahmin edebilmektedirler. Özellikle kişinin düşüncesi gerçekte olandan farklı olduğunda yani düşüncesi yanlış olduğunda (yanlış inanç), kişinin kendi düşüncesine/inançlarına dayanarak eylemde bulunacağını belirtebilmektedirler (örn., havuz kapalı olduğu halde bir kişinin havuza gitme davranışının, kişinin havuzun kapalı olduğunu bilmiyor olması ya da havuzun açık olduğunu sanması ile açıklanması) (Keçeli-Kaysılı ve Acarlar, 2011; Wimmer ve Perner, 1983).Yanlış inanç olarak adlandırılan bu aşama kişinin kendisinin ve başkalarının ne düşündüğüne ilişkin inançları doğrultusunda eylemde bulunmasıdır şeklinde tanımlanmaktadır (Dennett, 1978). Diğer bir deyişle zihinsel durumları anlama, kişilerin dünyaya ilişkin nesnel bakış açılarının olduğunu da kavramayı gerektirmektedir. Bu beceriyi ölçmemize imkan veren paradigma ise yanlış inanç işlemleridir (beklenilmeyen içerik, görünüm-gerçeklik, beklenilmeyen yer değişikliği vb.) (Wimmer ve Perner, 1983). Bu işlemlerde genellikle çocuklara, karakterlerin inançları ve istekleri ile ilgili bilgi verilerek eylemleri hakkında tahminde bulunmaları istenmektedir (daha ayrıntılı bilgi için bkz., Keçeli-Kaysılı, 2013).

Normal gelişen (NG) çocuklarda 4 yaşlarında zihin kuramında gözlenen değişimi açıklayan tek bir cevabın olmadığı söylenebilir. Zihin kuramını açıklayan teorilerden biri dört yaşında gözlenen bu değişimleri, dil ile ilişkisi bağlamında ele almaktadır. Bebeklerin dil kazanımından önce, yani söz öncesi dönemde sosyal bilişsel becerileri kazandıkları bilinmektedir. Örneğin diğer kişiyle ortak dikkat kurmak için kişinin bakışlarını takip etme, kişilerin dikkatlerini başka kişiye, nesneye ya da olaya yönlendirmek için seslendirmeler ya da gösterme, işaret etme gibi jestler kullanma gibi amaçlı iletişim becerileri bebeklerin sosyal bilişsel anlayışlarındaki değişimin ve zihni anlamanın bir göstergesidir (Carpenter, Nagell ve Tomasello, 1998) ve bu beceriler zihin kuramının öncülleri olarak tanımlanmaktadır (Miller, 2006). Bu dönemden başlayarak 5 yaşına kadar olan dönem çocukların zihin kuramının gelişmeye devam ettiği dönemdir ve aynı zamanda dil kazanımının önemli aşamasıdır. Bu eş zamanlı gelişim her ikisi arasındaki ilişkinin incelenmesine neden olmaktadır (Gopnik, 1990). Yapılan bu derleme çalışması, bu ilişkinin doğasını dilin bileşenleri bağlamında ayrıntılı olarak ele almayı amaçlamıştır.

Çocukların daha karmaşık ve daha soyut zihinsel durumları anlamalarında dilin önemli bir rolü olduğu pek çok araştırmacı tarafından vurgulanmıştır. Bu ilişki NG çocuklarda, otizm spektrum bozukluğu(OSB) olan çocuklarda, özgül dil bozukluğu olan çocuklarda (Miller, 2001) ve işitme engeli olan çocuklarda (Örn., KeçeliKays1l, 2013; Milligan, Astington, ve Dack, 2007; Tager-Flusberg ve Joseph, 2005; Woolfe, Want ve Siegal, 2002) ortaya çıkarılmıştır. Bu araştırmaların bazıları dil ve zihin kuramı arasında ilişki olup olmadığı sorusunun da ötesinde bu ilişkinin nasıl yapılandığına odaklanmıştır (Aksu-Koç, Aydın, Avcı, Sefer ve Yaşa, 2005; De Villiers ve Pyers, 2002; Hale ve Tager-Flusberg, 2003; Granti, 2004; Lohmann ve Tomasello, 2003; Shatz, Diesendruck, Martinez-Beck ve Akar, 2003). Zihin kuramı ile dil ilişkisinin doğası hem NG çocuklarda hem de zihin kuramında güçlük yaşadıkları bilinen özel gereksinimli çocuklarda zihin kuramı kazanımını anlamamıza yardımcı olacaktır. Çünkü başarılı bir iletişim için zihin kuramının gerekli olduğu, zihin kuramının öğrenilmesi için de dilin gerekli olduğu söylenebilir. Bununla birlikte bu ilişkinin doğasının açığa çıkması, zihin kuramını destekleyen müdahale programlarının içeriğine dilbilimsel hedeflerin de dâhil edilmesini sağlayabilecektir.

$\mathrm{Bu}$ derleme çalışmasında genel dil performansı ve zihin kuramı arasındaki ilişki ele alınmakla birlikte dilde özellikle sözdizimive anlambilgisi bileşenlerinin bu ilişkideki rolü üzerinde durulmuş ve alanyazındaki bulgular ışığında bu ilişkinin doğası ortaya koyulmaya çalışılmıştır. 
Okulöncesi dönemde zihin kuramında yanlış inancın kazanımını açıklayan teoriler incelendiğinde kuram teorisi, performans temelli teoriler ve dile dayalı teorilerin öne çıktığı görülmektedir. Dile dayalı teorilerin diğerlerinden farkını vurgulamak amacıyla izleyen bölümde dile dayalı teorilerin yanı sıra kuram teorisi ve performans temelli teorilere de yer verilmektedir.

\section{Zihin Kuramı Kazanımını Açıklayan Teoriler}

Kuram teorisini (Theory theory) savunanlara göre çocuklar, dört yaş döneminde zihni anlamada kavramsal değişimler yaşamaktadırlar. Bu kavramsal değişimlerle zihne ilişkin bilgiler kastedilmektedir ve bu bilgiler günlük yaşam çerçevesinde bireysel deneyimlerle şekillenmektedir (Gopnik ve Wellman, 1992;Wellman, Cross ve Watson, 2001). Bu kavramlar, kişinin sezgisel teorileri ile düzenlendiği için bu kavramsal değişim süreci "teori oluşumu" terimi ile açıklanmaktadır. Çocuklar basitleştirme ve yeni kanıtları birleştirme gibi faktörleri kullanarak sosyal ve psikolojik dünya hakkında teoriler oluşturmaktadır. Diğer bir deyişle çocuklar bilim insanları gibi tutarlı değerlendirmeler yaparak dış dünyayı anlarlar ve değerlendirmeleri sonucunda görüşlerini düzenlerler. Bu süreçte, zihinle ilgili tahminlerde bulunarak, açıklamalar yaparak ve kanıtları değerlendirerek aktif rol oynarlar. Bunun yanı sıra gelişim sürecinde gözlenen gelişim oluşturulmuş olan teorilerin de değişmesine yol açabilmektedir (Gopnik ve Wellman, 1992).

Performans temelli teoriler (Performance based theories) zihin kuramındaki değişimleri, belirli bir alandaki kavramsal değişimden çok genel bilişsel değişimlerle açıklayan teorilerdir. Performans temelli teoriler; doğuştanc modüler teori (nativist modular theory) ve yürütücü işlev teorisi (executive function theories) olmak üzere iki gruba ayrılmaktadır.

Doğuştancı modüler teoriye göre küçük yaştaki çocukların inanç kavramına ilişkin temsili düşünceleri vardır ancak diğer bilişsel faktörler nedeniyle yanlış inanç işlemlerindeki performansları maskelenmektedir (Baron-Cohen, 1995; Scholl ve Leslie, 2001). Araştırmacılar, 4 yaşından küçük çocukların yanlış inanç işlemlerinde başarısız olmalarını, işlemleri çözmede gerekli olan bilgi işlem kaynaklarının yetersizliğine bağlamaktadırlar. Bu yaklaşıma göre genel bilişsel mekanizma ile birlikte çalışan ve "Zihin Kuramı Mekanizması" (Theory of Mind Mechanism-ToMM) olarak adlandırılan özel alan sayesinde, yanlış inanç ve ilişkili problemler çözülmektedir. Yanlış inanç işlemlerinde başarılı olamama, kavramsal ve temsili sınırlılıklardan değil, performansla ilişkili faktörlerden kaynaklanmaktadır. Eğer böyle bir alan varsa aynı zamanda bu alanın bozukluğundan da söz edilebilir ve otizmde olduğu gibi sosyal etkileşim ve sosyal bilişte problemler gözlenebilir (Wellman ve Lagattuta, 2000).

Yürütücü işlev teorileri ise 4 yaşlarında zihin kuramındaki temel değişimleri, çalışma belleği ve ketleme davranışları gibi yürütücü işlev süreçlerindeki gelişime bağlamaktadır. Zihin kuramı ve yürütücü işlevler arasındaki güçlü ilişkiyi ortaya koyan araştırmalar bulunmaktadır (Carlson ve Moses, 2001) ve bu araştırmaların bulguları, yürütücü işlev ve doğuştancı modüler teorilerine destek sağlamaktadır.

Okulöncesi dönemde zihin kuramı gelişimi ile ilgili alanyazında kuram teorisi ve performans temelli teorilerin yanı sıra zihin kuramında gözlenen değişimleri, dil ile ilişkilendiren ve dilin rolüne dayandıran araştırmalar da bulunmaktadır. İlişkinin zihin kuramından dile doğru olduğunu öneren hipotez, bilişsel gelişim araştırmalarının temel dayanağı olan Piaget'nin (1980; Akt., Astington ve Jenkins, 1999) düşüncenin dile önderlik ettiği görüşüyle tutarlılık göstermektedir. Bu bakış açısına göre, zihin kuramı dilbilimsel temsillere dayalı değildir. Çocuklar ilk olarak yanlış inanca ilişkin kavramsal bilgiyi edinirler, daha sonra dil bu gelişimi yansıtır. Bu bakış açısı yanlış inanç anlayışının içsel modüler sisteme bağlı olduğu anlayışıyla da tutarlılık göstermektedir (Baron-Cohen, 1995). Özellikle söz öncesi dönemdeki zihin kuramının öncülleri olan ortak dikkat, amaçlı iletişim gibi becerilerin dil kazanımını desteklediğine ilişkin kanıtlar, bu görüşün açıklamaları içinde yer almaktadır (Malle, 2002). Bunun yanı sıra bazı bulgular, örneğin dil yeteneğini kaybeden bir yetişkinin (Varley, 1998; Akt.,Astington ve Jenkins, 1999) ya da dilde özellikle de dilbilgisi alanında ciddi güçlükler yaşayan başka bir yetişkinin (Apperly, Samson, Carroll, Hussain ve Humphreys, 2006) yanlış inancı anlama becerisinin kaybolmaması zihin kuramının dile dayanmadığı görüşünü desteklemektedir. Baron-Cohen'e 
(1995) göre OSB olan bazı çocukların, dili kazansalar da zihin kuramındaki problemleri çözemediklerini gösteren bulgular, dilin zihin kuramından bağımsız bir alan olduğuna işaret etmektedir.

Zihin kuramı ve dil arasında ilişki olmadığını ve ilişkinin başka faktörlerden kaynaklandığını savunan görüşe göre dil ve zihin kuramının gelişsimini sağlayan başka faktörlerin önemli olması nedeniyle dil ve zihin kuramı ölçümlerinin ilişkili çıktığı belirtilmektedir. Bazı bakış açılarına göre, çocukların daha karmaşık kuralların nedeninin anlaşılmasını sağlayan, çalışma belleği veya yürütücü işlevlerin gelişimi gibi faktörler içseldir. Bu içsel faktörler, zihin kuramı ve dil işlemlerindeki problemleri çözmede kullanılır (Zelazo ve Jacques, 1996). Diğer bakış açılarına göre bu faktör dışsaldır ve çocuğun sosyal ve kültürel etkinliklere katılımını destekler (Nelson, 1996; Akt. Astington ve Jenkins, 1999). Bir başka açıklamaya göre ise zihin kuramı ve dil, birbirinin gelişimini destekleyen iki yönlü bir ilişki sergilemektedir (Shatz, 1994; Akt. Astington ve Jenkins, 1999). Malle (2002) ise ilişkinin yönünün, gelişimin farklı dönemlerinde değişebileceğini belirtmektedir. Malle’ye (2002) göre söz öncesi dönemde zihin kuramı, dili destekler görünmekte iken daha sonraki dönemlerde ise ilişkinin yönü tam tersi biçimde yapılanmaktadır.

Zihin kuramının dile dayandığını savunan görüşlere aşağıda değinilmektedir. Zihin kuramının dile dayandığını savunan görüşün iki farklı açıklaması vardır. Birinci açıklama zihin kuramı işlemlerinin dile dayalı işlemler olması nedeniyle zihin kuramının dile dayandığı şeklindedir. İkinci açıklamada ise zihin kuramı işlemlerinden bağımsız olarak zihin kuramı dile dayanmaktadır.

\section{Zihin Kuramı İşlemleri Dile Dayanmaktadır}

Zihin kuramını değerlendirme amacıyla kullanılan yöntemlerin çoğu dile dayanmaktadır. Bu yöntemlerde sıklıkla, çocuklara hikâye anlatılmakta ya da uygulamacı işlemlerdeki materyaller hakkında konuşurken çocuklar dinlemektedirler. Çocuklar, bu girdiyi anlamak ve uygulamacının sorularını işlemden geçirerek cevap vermek zorundadır. Verilen cevap sözel olmayan bir cevap olsa bile soruyu cevaplaması için iyi düzeyde dil becerilerine ihtiyaç duyulmaktadır. Bu nedenle 3 yaş çocuklarının yanlış inancı anladıkları fakat işlemlerin dilbilimsel karmaşıklığından dolayı standart yanlış inanç testlerinde performanslarını sergileyemedikleri düşünülmektedir (Astington ve Jenkins, 1999).

Yapılan bir meta-analiz çalışmasında yanlış inanç işlemlerinin dilbilimsel özellikleri incelenmiştir. Çalışma sonucunda araştırmacılar özellikle küçük yaşlarda (3 yaş) performansta bir takım değişiklikler olsa da bu farklılığın, zihin kuramında başarılı olma yaşını istatistiksel olarak etkilemediğini bildirmişlerdir (Wellman ve ark., 2001). Yanlış inanç işlemlerinde genellikle soru “Ayşe topun nerede olduğunu düşünüyor?" şeklinde yöneltilmektedir. Bu soru bileşik bir tümcedir ve yan tümce yapısı içermektedir. Bazı araştırmalarda bu soru tümcesi karmaşık bir yapı barındırması nedeniyle değiştirilerek "Ayşe topu bulmak için nereye bakacak?" şeklinde yöneltilmiştir. Araştırmacılar bu değişikliğin, işlemlerdeki başarı yaşını değiştirmediğini bildirmişlerdir. Siegal ve Beattie (1991), işlemlerin dilbilgisel yapısını incelemek amacıyla yaptıkları çalışmalarında "nereye bakacak?" sorusunu değiştirmişlerdir. Çalışmalarında hikâyeler kullanmışlardır. Hikâyeler yer değişikliği işlemini barındırmaktadır: "Jane kedisini bulmak istiyordu. Jane kedisinin mutfakta olduğunu düşünüyordu. Ama kedisi gerçekte banyodaydı. Jane kedisini bulmak için nereye bakacak?”. Bu işlemdeki soru, çocuklar tarafından "Jane kedisini bulmak için nereye bakmalı?" şeklinde yorumlanabileceği ve kedinin gerçekte bulunduğu yerin seçilebileceği düşünüldüğü için değiştirilmiş ve "Jane kedisini bulmak için ilk olarak nereye bakacak?" şeklinde yöneltilmiştir. Araştırmacılar, çalışma sonucunda 3 yaşındaki çoğu çocuğun ikinci koşulda daha başarılı olduklarını bulmuşlardır.

İşlemlerdeki dilbilgisel karmaşıklığın azaltılması, bir başka işlem olan beklenilmeyen bağlam işleminde de denenmiştir (Lewis ve Osborne, 1990). Bu işlemde çocuklara bir kutu gösterilip kutunun içinde ne olduğunu tahmin etmeleri istenmektedir. Ardından kutunun içindeki nesne gösterilip tekrar kutuya koyulduktan sonra kutunun içinde ne olduğunu düşündükleri sorulmuştur. Araştırmacılar, çocukların bu sorunun önceki düşünceleriyle ilgili olduğunu anlamayabileceklerini savunmuşlardır. Eğer bu varsayım doğru ise test sorusuna zamanı belirten sözcük eklemenin çocukların performansını etkileyeceği düşünülmüştür. Çalışmalarında 
çocuklara, üç sorudan biri yöneltilmiştir: "Kutuda ne olduğunu düşünmüştün?/Kutunun kapağ kapalıyken kutuda ne olduğunu düşünmüştün?/Kutunun kapağını açmadan önce içinde ne olduğunu düşünmüştün?”. Araştırmacılar, soru "açmadan önce" şeklinde zamanı belirten sözcükle yöneltildiğinde üç yaş çocuklarının daha başarılı olduklarını bulmuşlardır. Bu araştırmanın sonucu, aynı zamanda işlemlerdeki tümcelerin dilbilgisel karmaşıklı̆̆ının arttırılmasının, performansı olumsuz yönde etkilemediğini de göstermektedir. Özgül dil bozukluğu olan çocuklarla yapılan bir çalışmada da çocukların performansının işlemlerde yöneltilen soruların dilbilgisel karmaşıklığından etkilenip etkilenmediği incelenmiştir (Miller, 2001; 2004). Araştırmada, "Sally topu bulmak için nereye bakacak?" sorusunun, "Sally topun nerede olduğunu düşünüyor?" sorusuna göre özgül dil bozukluğu olan grupta performansı daha olumlu yönde etkilediği, daha küçük yaştaki NG kontrol grubunda ise sorulardaki bu değişimin performansta bir değişiklik yaratmadığı görülmüştür.

İşlemlerin dilbilgisel yapısının performansı etkileyeceği varsayımı, zihin kuramının dile dayalı olup olmadığını tartışmaktan çok bunu test etmekte kullanılan yöntemlerin sınırlılıkları üzerinde durmaktadır. Bu varsayımdan yola çıkılarak dilin tamamen çıkarıldığı işlemler de geliştirilmiştir. Call ve Tomasello, (1999) şempanzelerde kullanılabilecek sözel olmayan yanlış inanç işlemleri geliştirmiş̧ler ve bu işlemleri çok az uyarlama yaparak NG çocuklarda denemişlerdir. Bu işlemler saklama ve bulma oyununa dayanmaktadır. Ortamda iki yetişkin bulunmaktadır (iletişimci ve nesneyi saklayan). Saklayan yetişkin çocuğun sevdiği bir nesneyi çocuğa gösterip kutulardan birine saklayacağını açıklamaktadır. Daha sonra saklayan kişi nesneyi iki kutudan birine saklamakta ancak çocuk aradaki paravan nedeniyle nesnenin saklandığ 1 yeri görmemektedir. Ancak her iki yetişkini de görmekte ve böylece iletişimci olarak ortamda bulunan kişinin nesnenin nereye saklandığından haberdar olduğunu izlemektedir. İletişimci odandan ayrıldığında saklayan kişi paravanı açarak kutuların yerini değiştirmektedir. İletişimci olan yetişkin geri döndüğünde nesnenin nerede olduğunu (yerleri değiştirilmeden önce nesnenin bulunduğu yeri işaret ederek) bir çubukla göstermektedir. Ardından çocuğun iletişimcinin yanlış inancını göz önünde bulundurarak doğru kutuyu seçmesi beklenmektedir. 5 yaşındaki çocuklar bu testte başarılı olmuşlar fakat küçük yaştaki çocuklar ve şempanzeler başarılı olamamışlardır.

Yanlış inanç işlemlerinde dili basitleştirme bazen performansı olumlu yönde etkilese de tamamen dilin çıkarıldığı işlemler NG çocuklar için daha kolay olmamaktadır (Astington ve Baird, 2005; Astington ve Jenkins, 1999). Yanlış inanç işlemlerinde kullanılan dil ve dilbilimsel karmaşıklık daha çok yetersizlikten etkilenmiş çocuklar için güçlükler yaratabilmektedir (Miller, 2004). Bu nedenle zihin kuramının nasıl değerlendirildiği önemli bir konu olmaktadır. Diğer taraftan şimdiye kadar çocukların, dilbilimsel becerilere sahip olmadan inançları ifade edebildiklerini gösteren bir kanıt bulunmamıştı. Sözel olmayan işlemlerden edinilen bulgular, zihin kuramının dile dayandığı hipotezini desteklemektedir. Yani dilbilimsel gelişim zihin kuramı gelişimini desteklemektedir.

Zihin kuramının dile dayandığını savunan bir diğer açıklamada zihin kuramı kazanımında, dilin belli özelliklerinin öncül olduğu savunulmaktadır.

\section{Zihin Kuramı İșlemlerinden Bağımsız Olarak Zihin Kuramı Dile Dayanmaktadır}

Milligan ve arkadaşları (2007), NG çocuklarda yanlış inanç ve dil becerileri arasındaki ilişkiyi inceleyen 104 çalışmayı meta-analiz yöntemiyle incelemişlerdir. Çalışma sonucunda yanlış inanç performansının kronolojik yaştan bağımsız olarak, dil becerileri ile ilişkili olduğu bulunmuştur. Yanlış inanç performansındaki değişkenliğin \%12'si alıcı sözcük dağarcığı, \%23'ü anlambilim, \%27'si genel dil, \%29'u sözdizimi ve \%44'ü yan tümceleri anlama ile açıklanmıştır. Bu noktada dilin hangi bileşenlerinin zihin kuramı ile ilişkili olduğu sorusu akla gelmektedir. İlerleyen bölümde dil ve zihin kuramı arasındaki ilişki genel dil ve dilin bileșenleri bağlamında aktarılmaktadır.

\section{Genel Dil Becerilerinin Zihin Kuramındaki Rolü}

$\mathrm{Bu}$ soruya yanıt arayan araştırmalarda, genellikle formal değerlendirme araçları kullanılarak, alıcı sözcük dağarcığı, biçimbirim bilgisi/sözdizimi, alıcı ve ifade edici sözdizimi ve anlam bilgisi incelenmiştir. Zihin 
kuramında genel dil becerilerinin önemli olduğu varsayımının en önemli kanıtları, boylamsal desende planlanmış araştırmalardan gelmektedir. Örneğin NG çocukların okulöncesi dönemdeki dil performansları ile daha sonraki yaşlarda gözlenen zihin kuramı işlemlerindeki performansları arasındaki ilişki incelendiğinde genel dil becerilerinin (Farrar ve Maag, 2002), sözcük dağarcığı performansının (Hughes, 1998) ve sözdizimi becerilerinin (Astington ve Jenkins, 1999) zihin kuramını yordadığı bulunmuştur. Astington ve Jenkins, zihin kuramı ve dilin farklı bileşenleri arasındaki ilişkiyi incelemek amacıyla 3 yaşındaki çocukları, standart yanlış inanç işlemleri ile 7 ay süresince boylamsal olarak 3 farklı zamanda değerlendirmişlerdir. Dil becerileri, dil testi ile değerlendirilmiş ve bu dil testindeki anlam bilgisi ve sözdizimi ile ilgili maddelerden alınan puanlar ayrılarak incelenmiştir. $\mathrm{Bu}$ araştırmada erken dönemdeki zihin kuramı performansı, daha sonraki 3 farklı zaman dilimde değerlendirilmiş olan dil performansını yordamamıştır. Ancak erken dönemdeki dil performansının, daha sonraki zaman dilimlerinde değerlendirilen zihin kuramı performansını yordadığı bulunmuştur. Bunun yanı sıra anlam bilgisi ve sözdizimi performanslarına ayrı ayrı bakıldığında anlam bilgisinin zihin kuramı performansına katkısı olmadığı ancak sözdiziminin katkısı olduğu bulunmuştur. Slade ve Ruffman (2005) dil ve zihin kuramı arasındaki ilişkinin başka faktörlerden etkilenip etkilenmediğini ortaya çıkarmak amacıyla yaptıkları çalışmaya çalışma belleği ile ilgili ölçümleri de eklemişlerdir. Boylamsal desende planladıkları araştırmalarında zihin kuramı ve dil arasında iki yönlü bir ilişki olduğu ve bu ilişkide sözdizimi ve anlam bilgisinin eşit katkısı olduğu bulunmuştur.

Görüldüğü üzere boylamsal desende planlanmış çalışmaların sonuçları genel dilin, zihin kuramındaki başarıyı açıkladığını göstermektedir. NG çocuklarda dilin kullanım bilgisi, anlam bilgisi ve biçimbirim bilgisi/sözdizimi bileşenleri birbiriyle güçlü bir ilişkiye sahiptir. Her ne kadar dilin bu üç bileşeninin zihin kuramı ile ilişkisi ortaya koyulmuş olsa da her birinin farklı bir rolünün olduğu da düşünülmektedir. Bu bağlamda dilin hangi özelliklerinin zihin kuramı ile ilişkili olduğu sorusu gündeme gelmektedir.

Dilin kullanım bilgisi bileşeni ile zihin kuramı arasındaki ilişkiyi inceleyen araştırmalar, çoğunlukla dilbilimsel çevrenin zihin kuramı ile ilişkisine yoğunlaşmışlardır. Zihin kuramının sosyokültürel açıklamasına göre çocuklar, zihin kuramını sosyal yaşam bağlamında öğrenmektedirler. Sosyal yaşama katılım ise diğerleriyle gerçekleştirilen sohbet deneyimleri ile mümkün olmaktadır. Sohbet deneyimleri sayesinde çocuklar, zihinsel dünyaya dâhil olabilir ve zihinlerin etkileşimlerini keşfedebilirler. Dilbilimsel çevredeki bu keşifleri sırasında inançların değişebileceğini, isteklerin farklılaşabileceğini, duyguların ortaya çıkabileceğini öğrenirler (Astington ve Baird, 2005; Dunn ve Brophy, 2005). Zihinsel durumların ve duyguların paylaşıldığı ailelerde büyüyen ve bu sohbetlere katılan NG çocukların, zihni ve duyguları anlama ile ilgili değerlendirmelerde daha başarılı olduklarını gösteren araştırmalar bulunmaktadır (Cutting ve Dunn, 2006; Dunn ve Brophy, 2005: Yağmurlu, Kazak-Berument ve Çelimli, 2005).

Bazı araştırmacılar, anlam bilgisinin zihin kuramı gelişimindeki rolüne daha çok ağırlık vermektedirler. Bu alanda yapılan araştırmalarda, genelde sözcük dağarcığı özelde ise bazı sözcüklerin zihin kuramı ile ilişkisi incelenmektedir. Dilin anlam bilgisi bileşeninin ele alındığı araştırmalara genel dil ve zihin kuramı ilişkisinin aktarıldığı bölümde yer verilmiştir. İzleyen bolümde zihinsel durumları ifade etmek için kullanılan eylemlerin kazanımı ve zihin kuramı ile ilişkisi ele alınmıştır.

\section{Anlambilgisinde Zihinsel Durum İfade Eden Eylemlerin Zihin Kuramındaki Rolü}

Zihinsel dünya gözlenemeyen inançlar, istekler ve duygular gibi soyut kavramlar dünyasıdır. Çocukların bu zihinsel durum içeren kavramları nasıl kazandıklarının açıklaması karmaşıktır (Astington ve Baird, 2005).Alanyazında bu amaçla yapılan araştırmalarda bu eylemlerin gelişimi incelenmiştir. Bu araştırmalara göre istek bildiren eylemler ilk kullanılan eylemlerdir. 2 yaşlarındaki çocukların kullandıkları sözcükleri annelerinden aldıkları bilgiye dayanarak değerlendiren Bretherton ve Beeghly (1982), çocukların bu yaşlarda sıklıkla psikolojik durum ifade eden (aç, susa, vb), alg1 ifade eden (gör, bak, sıcak/soğuk vb) ve duygu ifade eden (mutlu, üzgün, vb) sözcükleri kullandıklarını bulmuşlardır. Zihin kuramının asıl elemanları olduğu düşünülen istek ve inanç eylemleri ise yukarıda bahsedilen kategorilere göre daha az kullanılmış olsa da istek ifade eden eylemlerin 
bu yaşta inanç ifade eden eylemlere göre daha sık kullanıldığı gözlenmiştir. Bartsch ve Wellman (1995) da 2 yaşlarında istek, 3,5 yaşından başlayarak daha sonraki dönemlerde de inanç ifade eden eylemlerin kullanıldığını ve çeşitlendiğini belirtmişlerdir.

Zihinsel durum ifade eden eylemlerin kullanımı aynı zamanda zihinsel durumları anlamaya da işaret eder ve bu nedenle zihin kavramının gelişimini yansıtır (Moore, Bryant ve Furrow, 1989). Bil ve düşün eylemleri ilk kullanılmaya başlanan zihinsel durum ifade eden eylemlerdir (Bartsch ve Wellman, 1995). Bilmek ve düşünmek arasındaki en önemli ayırım, bil kullanılan tümcenin doğru, düşün kullanılan tümcenin ise doğru olmama ihtimalinin olmasıdır. Sözcüklerin ifade ettikleri bu anlamlar açısından ayırt edilebilmesi de araştırmalarda incelenmiştir. 3 yaştaki çocuklar bu ayrımı yapamazken 4 yaşındaki çocuklar bu iki eylem arasında ayırım yapabilmektedirler (Abbeduto ve Rosenberg, 1985; Moore ve ark., 1989). Moore ve arkadaşları (1989),3-8 yaşlarındaki çocukların, 4 yaşlarında bil ve düşün/bil ve tahmin et eylemlerini ayırt edebildiklerini, bu gelişimin ise 5 yaşta tamamlandığını belirtmişlerdir. Buna karşın düşün ve tahmin et eylemleri arasındaki ayırımın bu yaşlarda anlaşılamadığı da gözlenmiştir. $\mathrm{Bu}$ sonucu zihinsel durum ifade eden eylemlerin anlamlarını kavramanın, sosyal bağlamlardaki deneyimlerle kazanılmadığı şeklinde yorumlamışlardır (Moore ve ark., 1989).

Zihinsel durum ifade eden eylem bilgisinin, özellikle anlamlarının kavranılmaya başlandığı yaşlar düşünüldüğünde zihin kuramı (yanlış inanç) ile ilişkili olduğu görülmektedir. Zihin kuramı ve zihinsel durum ifade eden eylemlerin kullanımı arasındaki ilişkiye ilişkin kanıtların farklı dillerden de sağlandığı görülmektedir. $\mathrm{Bu}$ amaçla yapılan bir çalışmada Peru'da konuşulan Quechua dili incelenmiştir. Bu dilde zihinsel durum ifade eden eylemler kullanılmamaktadır. "Düşün, inan" gibi eylemler dolaylı yoldan ifade edilmektedir. Örneğin “düşün" veya "reddet” eylemleri "söyle" sözcüğü ile ifade edilmektedir (Örn. "Ne düşünür?" yerine "Ne söyler?”). Araştırmada 4-8 yaşlarındaki çocukların yanlış inanç işlemi olan görünüm gerçeklik işleminde, batı ülkelerinde yaşayan çocuklarla benzer performans gösterdikleri, diğer yanlış inanç işlemlerinde ise güçlükler yaşadıkları bulunmuştur. Bu sonucun Quechua dilinde zihinsel durum ifade eden eylem bulunmamasından kaynaklanabileceği belirtilmekle birlikte, görünüm gerçeklik işleminde başarılı olmaları, bu çocukların zihin kuramını, bu kavramlardan bağımsız olarak ya da başka kavramlara bağlı olarak geliştirmiş olabileceği ile açıklanmıştır (Vinden, 1996). Bir başka çalışma ise Çince konuşan çocuklarla gerçekleştirilmiştir. Çincede "düşün" yerine kullanılan üç eylem bulunmaktadır. Çincede de Türkçede olduğu gibi doğrudan yanlış inanca atıfta bulunulabilecek "san” eylemi bulunmaktadır. İşlemler bu üç eylem kullanılarak ayrı ayrı yöneltildiğinde çocukların performanslarının farklılaştığı gözlenmiştir. İşlemdeki soru bu eylemle yöneltildiğinde 3 yaştaki çocukların yarısı başarılı olurken “düşün” sözcüğünün kullanıldığı işlemlerde çocukların \%20'si başarılı olmuşlardır (Lee, Olson ve Torrance, 1999). Bir başka çalışmada İngilizce, Brezilya İspanyolcası, Türkçe ve Portoriko İspanyolcası konuşan çocukların yanlış inanç performansları karşılaştırılmıştır (Shatz, ve ark., 2003). Türkçe ve Porto Riko İspanyolcasında kişinin yanlış inancı, "san” gibi özel eylem sözcükleri ile ifade edilebilmekte iken, diğer dillerde bunu karşılayan sözcük "düşün” dür. Araştırma sonuçlarına göre Türkçe ve Portoriko İspanyolcası konuşan çocukların, İngilizce ve Brezilya İspanyolcası konuşan çocuklara göre sorular zihinsel durum ifade eden eylem içerdiğinde (san veya düşün) daha başarılı oldukları görülmüştür. Bu sözcüklere sahip olan dillerin zihin kuramında daha avantajlı oldukları görülmektedir. Ancak bu avantajlı durum 3 yaşta değil 4 yaşta gözlenmiştir ve her iki çalışmada da (Lee ve ark., 1999; Shatz ve ark., 2003) sorular "nereye bakacak?" şeklinde zihinsel durum içermeden sorulduğunda diller arasında avantajlı bir durum gözlenmemiştir. Türkçe konuşan çocukların zihinsel durum belirten eylem sözcüklerinden en erken "san" sözcüğünü anladıkları, yanlış inanç işleminde kullanılan sorular "düşün” yerine "san” eylemini içerdiğinde Türkçe konuşan çocukların zihin kuramı kazanımının, İngilizce konuşan çocuklardan daha erken olduğu bulunmuştur (Aksu-Koç ve ark., 2005; Granti, 2004).

Farklı dillerde gerçekleştirilen bu çalışmaların pek çok açıklaması bulunabilir. Ancak her ne kadar sözcük dağarcığında zihinsel duruma atfen kullanılan eylemlerin dile özgü özellikleri zihin kuramında farklılıklara yol açmış olsa da bu farklılığın genel olarak zihin kuramındaki anlayışı değiştirdiği söylenemez. Diğer taraftan zihinsel durum ifade eden eylemlerin, sözdizimi yapısı içinde anlamlandırılarak (syntactic bootstrapping) 
öğrenildiği de savunulmaktadır (Tomasello, 1995; Akt., de Villiers, 2005). Bu görüşe göre çocuklar, sözdizimi bilgilerini sözcüğün anlamını çözmek ve öğrenmek için kullanabilirler. Diğer bir deyişle önceden bildiklerini kullanarak daha gelişmiş dili öğrenebilirler. Çocuk tümce içinde kullanılan yeni bir sözcük duyduğunda bağlamı inceleyerek hangi eyleme atıfta bulunulduğunu tahmin edebilir (de Villiers, 2005). Bir sonraki bölüm sözdizimi ve zihin kuramı ilişkisini açıklamakla birlikte bu eylemlerin de sözdizimi bağlamında nasıl öğrenildiği konusuna da açıklık getirecektir.

\section{Sözdiziminin Zihin Kuramındaki Rolü}

Zihinsel durum ifade eden eylemlerin kazanımı, zihinsel durumlarla ilgili olarak akıl yürütmede önemlidir. Dil geliştikçe zihinsel durumların temsili için gerekli olan sözdizimsel yapılar, bu zihinsel durumlarla ilgili olarak akıl yürütmede kaynak sağlar.

Sözdiziminin zihin kuramı gelişimindeki etkisiyle ilgili önemli açıklamalardan biri Jill de Villiers (de Villiers, 2005; de Villiers ve de Villiers, 2003) tarafindan önerilen dilbilimsel belirlemecilik teorisidir (Linguistic Determinism Theory). De Villiers'a göre yanlış inanç, gerçekliğin gözlenmesiyle değil dil ile kazanılır. Çalışmaları sonucunda yanlış inançla ilgili konuşmanın, yan tümceyi içeren karmaşık tümce kullanımını gerektirdiği sonucuna ulaşmıştır. İngilizcede zihinsel durum ifade eden eylemler (düşün, inan, bil) ve iletişim eylemleri (söyle) bu yapıyla birlikte kullanılmaktadır. Örneğin "John çikolatanın çekmecede olduğunu düşünüyordu/John thought that thechocolatewas in thedrawer" tümcesinde gömülü yan tümce "Çikolatanın çekmecede olduğu” tümcesidir. Bu yan tümce temel tümcedeki düşünmek eyleminin/yükleminin nesnesi olarak görev yapmaktadır. $\mathrm{Bu}$ nedenle bu yapı dilbilimde isim yan tümcesi (Object complements) olarak adlandırılmaktadır. Bu yapının zihin kuramındaki önemi, yanlış inancın ifade edilmesine olanak sağlıyor olmasıdır. Gömülü olan tümce yanlış olsa da tümcenin tamamı doğru olabilmektedir. Bundan dolayı "John çikolatanın çekmecede olduğunu düşünüyor" tümcesinde çikolata gerçekten çekmecede olmasa bile bunu söyleyen doğru söylüyor olabilir. Yani tümcenin doğruluğu, isim yan tümcesinin doğruluğundan bağımsızdır. Çocuklar, yan tümce yapısı yanlış olsa da yani aslında çikolata çekmecede değil dolapta olsa da, bu tümcenin doğru olabileceğini kavrayana kadar yanlış inancı temsil edemezler. Okulöncesi dönemde çocuklar dillerinin temel sözdizimi yapısını kullanmada uzmanlaşırlar ve İngilizcede isim yan tümcesi yapısını da bu yaşlarda (3-4 yaşlarında) kazanırlar. De Villiers ve Pyers'a (2002) göre bu yapının kazanılmasıyla yanlış inancı anlamak için gerekli olan temsili yapı da kazanılmış olmaktadır. Jill de Villiers çocukların bu yapıyı ilk olarak zihinsel olmayan söyle, anlat gibi iletişim eylemleri ile kullandıklarını varsaymaktadır. Daha sonra bu yapıyı zihinsel durum ifade eden eylemlerle kullanmaya başlamaktadırlar. Bundan dolayı zihinsel eylemleri içeren anlambilim ve sözdizimi arasında yakın bir ilişki vardır.

Çocukların yan tümceleri kullanarak karmaşık tümce kurmalarının ve bu tümceleri anlamalarının, zihin kuramındaki başarıyla ilişkili olduğu belirtilmektedir (de Villiers ve Pyers, 2002; Hale ve Tager-Flusberg, 2003; Lohmann ve Tomasello, 2003). Boylamsal bir çalışmada de Villiers ve Pyers (2002), 3-5 yaşlarındaki okulöncesi dönemindeki NG çocukların dil (yan tümceleri anlama) ve yanlış inanç becerilerini bir yıl içinde dört farklı zamanda değerlendirmişlerdir. Yan tümce yapısını anlama ve kullanma 12 işlemle diğer dilbilgisi yapılarından ayrılarak gözlenmiştir. Kullanılan 12 işlemin 6'sı iletişim eylemiyle (söyle, sor gibi), diğer 6'sı da zihinsel durum ifade eden eylemlerle (düşün gibi) yapılandırılmıştır. Araştırmada erken dönemdeki yan tümce yapısındaki başarının daha sonraki yanlış inanç performansını yordadığı bulunmuştur ve bu sonuç sözdizimi/biçimbirim bilgisinin diğer ölçümlerinden (OSU, dil örneğindeki diğer bileşik tümce yapıları) yani genel dildeki değişimlerden etkilenmemiştir. Ayrıca iletişim eylemlerinin kullanımının, yan tümce yapısında uzmanlaşmak için yardımcı olduğu da bulunan sonuçlar arasında yer almaktadır.

Zihin kuramı gelişiminde yan tümcenin rolü, deneysel desendeki çalışmalarda da incelenmiştir. Hale ve Tager-Flusberg (2003), üç farklı yanlış inanç öğretim yönteminin 3-5 yaşındaki 60 çocuğun zihin kuramı performanslarına etkisini incelemişlerdir. Her bir gruba verilen öğretim farklı dil stratejisini içermiş ve yer değişikliği işlemleri üzerine yapılandırılmıştır. Araştırmada bir gruba yanlış inanç öğretimi, bir gruba isim yan 
tümcesi öğretimi ve bir başka gruba da sıfat yan tümcesi öğretimi yapılmıştır. Bu çalışmada yanlış inancı yan tümce yapısıyla açıklaması beklenen grubun zihin kuramı performansı, yanlış inanç öğretimi yapılan grubun performansına benzer olarak artmıştır. Lohmann ve Tomasello da (2003), de Villiers'ın varsayımının önerdiği gibi yan tümce yapısını kullanmanın zihin kuramını desteklediğini belirtmişlerdir. Lohmann ve Tomasello, deneysel desende planladıkları araştırmalarında 3-4 yaşlarındaki 222 çocuğu, dört farklı öğretim grubuna atamışlar ve öğretimi, gruptaki çocuklarla bireysel olarak gerçekleştirmişlerdir. Eğitim sonunda çocukların yanlış inanç becerilerinde ilerleme göstermeleri için dilin gerekli olduğu bulunmuştur. Çünkü dilin hiç kullanılmadığı araştırmanın kontrol grubunun yanlış inanç performanslarında değişiklik olmamıştır. Bu çalışmanın sonucu da isim yan tümcesi yapısının çocukların yanlış inancı kavramsallaştırmalarına ve yanlış inanç hakkında konuşmalarına kaynak sağladığını göstermektedir. Ancak yukarıda açıklanan bu iki öğretim araştırması okulöncesi dönemdeki NG çocuklarda yan tümce yapısını anlama ve kullanma öğretiminin, yanlış inanç becerilerinin gelişmesinde önemli fakat gerekli olmadığını da göstermektedir. Çünkü her iki araştırmada da sadece yanlış inanç öğretimi yapılan gruplarda da son testteki performansların arttığı gözlenmiştir.

Türkçede yapılan iki çalışmanın da bu hipotezi desteklediği görülmektedir. Granti (2004), 3-6 yaşlarındaki 70 çocukla yürüttüğü araştırmada, zihin kuramı ile zihinsel durum belirten eylemler ve isim yan tümcelerini anlama ve kullanma arasındaki ilişkiyi incelemiştir. Araştırma sonuçları, isim yan tümcelerindeki performansların yaşla arttığını göstermiş̧tir. Ayrıca araştırmada yaşla birlikte yan tümce yapısını anlamanın ve kullanmanın da zihin kuramındaki başarıyı yordadığı bulunmuştur. Bir başka çalışmada Aksu-Koç ve arkadaşları (2005) 3-4 yaşları arasındaki 69 çocuğun zihin kuramı işlemlerindeki performansları ile isim yan tümcelerini kullanmaları ve kiplik eklerini anlamaları arasındaki ilişkiyi incelemişlerdir. Araştırmada -mA, -mAK, -DIK ve -AcAK eylemsileri ile kurulan isim yan tümceleri "söyle" sözcüğü ile oluşturulmuş ve 4 işlemde değerlendirilmiştir. Kiplik ekleri de 10 işlemde değerlendirilmiştir. Araştırma sonuçlarına göre grupların yan tümceleri kullanmaları ve kiplik eklerini anlamaları arasında fark bulunmamıştır. Regresyon analizleri yaşın isim yan tümcelerini yordadığını ancak kiplik eklerini yordamadığını göstermiştir. Bunun yanı sıra dildeki özel yapılar olan isim yan tümcelerini kullanma ve bilginin kaynağına işaret eden kiplik eklerini (Örn. -mIş, -DI, mIşDIr) anlama becerilerinin yaşla birlikte, zihin kuramında yanlış inanç işlemlerindeki performansını yordayan faktörler olduğu bulunmuştur. Bu araştırma sonuçları da isim yan tümcelerinin zihin kuramı ile ilişkisine işaret etmektedir.

Aksu-Koç ve arkadaşlarının (2005) araştırmasında incelenen kiplik ekleri Türkçede geçmişle ilgili konuşurken kullanılan eklerdir. Geçmişle ilgili konuşurken bu eklerden hangisinin kullanılacağı konuşmacının aktardığı olaya ilişkin bilgisine göre değişmektedir. Eğer konuşmacı olayı gördü ise (-DI) ekini, olayla ilgili bilgiyi başkasından almış ise (-mIş) ekini kullanır. Türkçe konuşan çocuklar bu ekleri önce (-DI) sonra (-mIş) olmak üzere 2 yaştan önce kullanılmaya başlamaktadırlar. 3 yaşlarına geldiklerinde kendi deneyimleri dışında gerçekleşmiş (-mIş) bir olaya atıfta bulunabilmekte ve bundan farklı olarak da bir olayla benzerlik gösteren kendi dolaylı deneyimlerine dayanarak, olaya ilişkin çıkarımlarda bulunabilmektedirler (-Dır) (Aksu-Koç, 1988; Aksu-Koç, 2009). Çocuklara bir balonun patlaması gösterildiğinde yani çocuk buna tanık olduğunda ya da patlamasına tanık olmadığı patlamış bir balon gösterildiğinde 3 yaşında doğru eki (-mIş ya da -DI) kullanarak olayı aktarmışlardır. Ancak sadece 4 yaşındakiler bir bebeğin tanık olduğu ve olmadığı olayı doğru ekle (mIşDır) aktarabilmişlerdir (Aksu-Koç, 1988). Bu sonuçlar kiplik ekleri ile zihin kuramının ilişkili olduğunu göstermektedir. Ayrıca Türkçe konuşan çocukların zihin kuramı kazanımının, Türkçeye özgü olan bu ekler nedeniyle daha erken yaşlarda olabileceği belirtilmektedir ( Aksu-Koç, 2009). Bu görüş de dilin biçim bileşeninin zihin kuramındaki rolüne ilişkin kanıt sağlamaktadır. 


\section{Sonuç ve Öneriler}

Bu derleme çalışması zihin kuramını dil ile olan ilişsisi bağlamında ele almıștır. Zihin kuramının kazanımı dile dayandıran teoriler genellikle genel dil ile zihin kuramı arasındaki ilişkiyi incelemişlerdir. Ancak bu derleme çalışmasında bu ilişkinin doğası incelenmek istenmiş ve bu nedenle isim yan tümceleri ve zihinsel durum ifade eden eylemlerin zihin kuramı ile ilişsisine değinilmiştir. Araştırma bulguları zihinsel durum ifade eden eylemleri ya da karmaşık tümce yapısı olan isim yan tümcelerini kullanmanın, zihin kuramı performansı ile ilişkili olduğunu göstermektedir. Bir başkasının düşüncesi ya da davranışlarını açıklamada zihinsel durum ifade eden eylemler kullanıldığında isim yan tümcelerine ihtiyaç duyulmakta ya da bu eylemlerin öğrenimi bu karmaşık tümcelerin kullanımı ile mümkün olmaktadır. Tümceler karmaşıklaştıkça iletişim ifade eden eylemlerden zihinsel durum ifade eden eylemlere doğru bir gelişim söz konusudur. Zihinsel durum ifade eden "san" ve "bil" eylemi ile kurulan yan tümceler, bu eylemlerin anlambilgisel özellikleri nedeniyle daha güçtür ve bu eylemler zihin kuramında yanlış inancın kazanıldığ 14 yaşlarında kazanılmaktadır. Türkçede de isim yan tümceleri kurmada kullanılan -DIK ve -AcAK eylemsilerinin kullanımı da 4 yaşlarında gözlenmektedir (Aksu-Koç, 2010). Bunun yanı sıra Türkçeye özgü olan kiplik eklerinin, zihin kuramı ile ilişkili olduğu düşünüldüğünde (Aksu-Koç ve ark., 2005) bu ilişkinin ilerde yapılacak olan çalışmalarla incelenmesi önemli görülmektedir. Farklı dillerde yapılan çalışmalar dil ve zihin kuramı arasındaki ilişkiyi de açıklığa kavuşturacaktır çünkü karmaşık tümce yapısı dillere göre farklılaşmaktadır ve dile özgü değişen özellikler nedeniyle alanyazına farklı bilgiler sunulabilmektedir. Örneğin Türkçe konuşan çocukların zihin kuramı kazanımının, Türkçeye özgü olan kiplik ekleri nedeniyle daha erken yaşlarda olabileceği belirtilmektedir ( Aksu-Koç, 2009).

$\mathrm{Bu}$ bulguların uygulamaya yansıması da önemli görülmektedir. Özellikle zihin kuramında güçlük yaşadıkları bilinen OSB olan çocuklara zihin kuramı öğretiminde zihin kuramı çoğunlukla tek başına bir alan olarak öğretilmektedir. Oysa dilin zihin kuramı ile olan ilişkisini gösteren bulgular düşünüldüğünde karmaşık tümce kullanımı ve zihinsel durum ifade eden eylemlerin öğretimi de önemli görülmektedir. Bu sayede öğretilen becerilerin genellenmesi de mümkün olabilecektir. Zihin kuramı ile ilişkili olduğu belirtilen bu yapıların bilinmesinin, değerlendirmede dikkat edilecek alanlara ve dildeki müdahale hedeflerinin belirlenmesine 1şık tutacağı düşünülmektedir. Dil ve zihin kuramı arasında bebeklikten itibaren gözlenen bir ilişki olduğu düşünüldüğünde, $\mathrm{NG}$ ve gelişimsel dil bozukluğu olan çocukların iletişim ve dil gelişimlerini desteklemede zihin kuramı, eğitimcilerin göz önünde bulundurması gereken bir alandır. 


\section{KAYNAKLAR}

Abbeduto, L., \& Rosenberg, S. (1985). Children's knowledge of the presuppositions of know and other cognitive verbs. Journal of Child Language, 12, 621-641.

Aksu-Koç, A. (1988). The acquisition of aspect and modality: The case of past reference in Turkish. Cambridge: Cambridge University Press.

Aksu-Koç, A. (2009). Evidentials: An interface between linguistic and conceptual development. In J. Guo, E. Lieven, N. Budwig, S. Ervin-Tripp, K. Nakamura \& Ş. Özçalışkan (Eds.) Crosslinguistic Approaches to the Psychology of Language: Research in the Tradition of Dan Isaac Slobin (pp.531-541). New York, London: Psychology Press, Taylor \& Francis Group.

Aksu-Koç, A. (2010). The Course of Normal language development in Turkish. In S. Topbaş \& M. Yavaş (Eds), Communication Disorders In Turkish (pp. 65-104). UK: Multilingual Matters.

Aksu-Koç, A., Aydın, Ç., Avcı, G., Sefer, N., \& Yaşa, Y. (2005, July). The relation between mental verbs and theory of mind performance: Evidence from Turkish children; Paper presented at International Association for the Study of Child Language [IASCL]; Berlin.

Apperly, I. A., Samson, D., Carroll, N., Hussain, S., \& Humphreys, G. (2006). Intact first- and second-order false belief reasoning in a patient with severely impaired grammar, Social Neuroscience, 1, 334-348.

Astington, J. W., \& Baird, J. A. (2005). Introduction: Why language matters. In J. W. Astington \& J. Baird (Eds.), Why language matters for theory of mind (pp. 3 -25). New York: Oxford University Press.

Astington, J. \& Jenkins, J. (1999). A longitudinal study of the relationship between language and theory of mind development. Developmental Psychology, 35, 1311- 1320.

Baron-Cohen, S. (1995). Mindblindness: an essay on autism and theory of mind. Cambridge, MA: MIT Press,

Bartsch, K., \& Wellman, H. M. (1995). Children talk about the mind. NewYork: Oxford University Press.

Bretherton, I., \& Beeghly, M. (1982). Talking about internal states: The acquisition of an explicit theory of mind. Developmental Psychology, 18, 906-921.

Call, J., \& Tomasello, M. (1999). A nonverbal false belief task: the performance of children and great apes. Child Development, 70, 381-395.

Carlson, S., \& Moses, L. J. (2001). Individual differences in inhibitory control and children's theory of mind. Child Development, 72, 1032-1053.

Carpenter, M., Nagell, K., \& Tomasello, M. (1998). Social cognition, joint attention, and communicative competence from 9 to 15 months of age. Monographs of the Society for Research in Child Development, 63 (4, Serial No. 255).

Cutting, A.L., \& Dunn, J. (2006). Conversations with siblings and with friends: Links between relationship quality and social understanding. British Journal of Developmental Psychology, 24, 73-87.

de Villiers, J. (2000). Language and ToM: What are the developmental relationships. In: S. Baron-Cohen, H. Tager-Flusberg and D. Cohen, Editors, Understanding other minds: Perspectives from developmental cognitive neuroscience (2nd ed.), Oxford University Press, Oxford, 83-123.

de Villiers, J. G. (2005). Can language acquisition give children a point of view? In J. W. Astington \& J. A. Baird (Eds.), Why language matters for theory of mind (pp. 186 - 219). New York: Oxford University Press. 
de Villiers, J. G., \& de Villiers, P. A. (2003). Language for thought: Coming to understand false beliefs. In D. Gentner \& S. Goldin-Meadow (Eds.), Language in Mind: Advances in the Study of Language and Cognition (pp. 335-384). Cambridge, MA: MIT Press.

de Villiers, J. G., \& Pyers, J. E. (2002). Complements to cognition: A longitudinal study of the relationship between complex syntax and false-belief understanding. Cognitive Development, 17, $1037-1060$.

Dennett, D. C. (1978). Beliefs about beliefs. The Behavioral and Brain Sciences, 1, 568-570.

Dunn, J. \& Brophy, M. (2005). Communication, relationships, and individual differences in children's understanding of mind. In J.W. Astington \& J.A. Baird (Eds.). Why language matters for theory of mind (pp. 50-69). Oxford: University Press.

Farrar, M. J., \& Maag, L. (2002). Early language development and the emergence of a theory of mind. First language, 22, 197-213.

Gopnik, A. (1990). Developing the idea of intentionality: Children's theories of mind. Canadian Journal of Philosophy, 20, 89-114.

Gopnik, A., \& Wellman, H. M. (1992). Why child's theory of mind really is a theory. Mind \& Language, 7, 145171.

Granti, T. (2004). The relationship between metacognitive vocabulary and theory of mind development, Unpublished master of arts dissertation, Boğaziçi University Master of Arts in Psychology, Istanbul.

Hale, C. M., \& Tager-Flusberg, H. (2003). The influence of language on theory of mind: a training study. Developmental Science, 6, 346-359.

Hughes C. (1998). Finding your marbles: does preschoolers' strategic behavior predict later understanding of mind? Developmental Psychology, 34, 1326-1339.

Keçeli-Kaysıl1, B. (2013). Zihin kuramı: Otizm spektrum bozukluğu olan ve normal gelişen çocukların performanslarının karşılaştırılması, Ankara Üniversitesi Eğitim Bilimleri Fakültesi Özel Eğitim Dergisi, 14(1), 83-106.

Keçeli-Kaysılı, B., \& Acarlar, F. (2011). Zihin kuramının 3-5 yaşları arasındaki çocuklarda gelişiminin yanlış inanç performansına göre incelenmesi. Kuram ve Uygulamada Eğitim Bilimleri. Educational Sciences: Theory \& Practice, 11(4), 1809-1826.

Lee, K., Olson, D., \& Torrence, N. (1999). Chinese children's understanding of false beliefs: the role of language. Journal of Child Language, 26, 1-21.

Lewis, C., \& Osborne, A. (1990). Three-year-olds' problems with false belief: Conceptual deficit or linguistic artifact? Child Development, 61, 1514-1519.

Lohmann, H., \& Tomasello, M. (2003). The role of language in the development of false-belief understanding: A training study. Child Development, 74, 1130 - 1144.

Malle, B. F. (2002). The relation between language and theory of mind in development and evolution. In T. Givon, \& B. F. Malle (Eds), The evolution of language out of pre-language, (pp. 265-284). Amsterdam: Benjamins.

Miller, C. A. (2001). False-belief understanding in children with specific language impairment. Journal of Communication Disorders, 34, 73 - 86.

Miller, C. A. (2004). False belief and sentence complement performance in children with specific language impairment. International Journal of Language \& Communication Disorders, 39, 191-213. 
Miller, C. A. (2006). Developmental relationships between language and theory of mind. American Journal of Speech-Language Pathology, 15, 142-154.

Milligan, K., Astington, J., Dack, L. (2007). Language and Theory of Mind: Meta- Analysis of the Relation Between Language Ability and False-Belief Understanding, Child Development, 78, 622-646.

Moore, C., Bryant, D., \& Furrow, D. (1989). Mental terms and the development of certainty. Child Development, 60, 167-171.

Premach, D., \& Woodruff, G. (1978). Does the chimpanzee have a theory of mind? The Behavioral and Brain Sciences, 4, 515-526.

Scholl, B. J., \& Leslie, A.M. (2001). Minds, modules, and meta-analysis. Child Development, 72, 696-701.

Shatz, M. Diesendruck, G. Martinez-Beck, I., \& Akar, D. (2003). The influence of language and socioeconomic status on children's understanding of false belief. Developmental Psychology, 39, 717-729.

Siegal, M., \& Beattie, K. (1991). Where to look first for children's knowledge of false beliefs. Cognition, 38, 112.

Slade, L., \& Ruffman, T. (2005). How language does (and does not) relate to theory of mind: A longitudinal study of syntax, semantics, working memory and false belief. British Journal of Developmental Psychology, 23, 117-141.

Tager-Flusberg, H., \& Joseph, R. M. (2005). How language facilitates the acquisition of false-belief understanding in children with autism. In J. W. Astington \& J. A. Baird (Eds.), Why language matters for theory of mind (pp. 298 - 318). New York: Oxford University Press.

Vinden, P. G. (1996). Junin Quechua children's understanding of mind. Child Development, 67, 1707-1716.

Wellman, H., Cross, D., and Watson, J. (2001). Meta-analysis of theory of mind development: The truth about false belief. Child Development, 72, 655-684.

Wellman, H. M., \& Lagattuta, K. H. (2000). Developing understandings of mind. In S. Baron-Cohen, H. TagerFlusberg, \& D. J. Cohen (Eds.), Understanding other minds: perspectives from autism (Second edition). New York: Oxford University Press.

Wimmer, H., \& Perner, J. (1983). Beliefs about beliefs: representation and constraining function of wrong beliefs in young children's understanding of deception. Cognition, 13, 103-128.

Woolfe, T., Want, S. C., \& Siegal, M. (2002). Signposts to development: Theory of mind in deaf children. Child Development, 73, 768-778.

Yağmurlu, B., Kazak-Berument, S., \& Çelimli, Ş. (2005). The role of institution and home contexts in theory of mind development. Applied Developmental Psychology, 26, 521-537.

Zelazo, P. D., \& Jacques, S (1996). Children's rule use: Representation, reflection, and cognitive control. In R. Vasta (Ed.), Annals of Child Development (Vol. 12, pp. 119-176). London: Jessica Kingsley. 


\title{
Summary
}

\section{The Relationship between Language and Theory of Mind: A Review}

\author{
Bahar Keçeli Kaysılı* \\ Ankara University
}

Purpose and Significance: The main purpose of this review of literature is to identify and clarify the hypothesis that tries to explain the acquisition of theory of mind and to discuss the relationship between theory of mind and language. This review focused on hypothesis argues that theory of mind depends on language. There are evidence and reasons to expect theory of mind and language to be related. But beyond the question of whether language plays a role in false belief understanding, a few research has been aimed at identifying more specifically the nature of this role.

Method: A review of literature on language and theory of mind is presented. The relationship between theory of mind and general language discussed. Finally to understand the nature of this relationship, literature based evidences in terms of syntax and related mental states were investigated.

Results: Theory of mind is necessary for communication through language and language offer a way to learn about theory of mind. One of the hypothesis that explains the acquisition of theory of mind, proposed that syntax and mental states verbs provides children to understand representational thoughts like false belief. de Villiers (2005), suggested that sentential complement is necessary for acquisition of theory of mind. Sentential complements are constructs that allows to embed tensed propositions under a main verb (e.g., John thought that the chocolate was in the drawer). Communication verbs (e.g., say, ask) and mental state verbs (e.g., think, know) can take sentential complements. This construct allows to express false beliefs via embedded sentence (whole construction may be true even though the embedded sentence is false).

Discussion and Conclusions: Different languages give different source of understanding about acquisition of theory of mind. Aksu-Koç and colleagues (2005) found that when false belief questions asked with "san-think false belief" the performance of Turkish-speaking children on these tasks was facilitated compared to Englishspeaking children.Results also indicated the fact that control of evidential marking and complement constructions were found to be significant predictors of false belief performance. These results suggest that number of linguistic factors need to be considered for theory of mind development. Cross-linguistic studies that will be conducted to address areas related to false belief understanding are important for understanding of theory of mind. This research area would give support to the implications for both typically developing children and children with special needs

\footnotetext{
*Lecturer, Dr., Ankara University, Faculty of Educational Sciences, Department of Special Education, Ankara, E-mail: bkaysili@ankara.edu.tr
} 